\title{
The esophagus/cardiac stomach region: site of attachment and internalization of infectious hematopoietic necrosis virus in challenged juvenile rainbow trout Oncorhynchus mykiss and coho salmon O. kisutch
}

\author{
Consetta M. Helmick ${ }^{1}$, J. Franklin Bailey ${ }^{2}$, Scott LaPatra ${ }^{3}$, Sandra Ristow ${ }^{1, *}$ \\ ${ }^{1}$ Department of Animal Sciences, Washington State University, Pullman, Washington 99164, USA \\ ${ }^{2}$ Electron Microscopy Center, University of Idaho, Moscow, Idaho 83843, USA \\ ${ }^{3}$ Clear Springs Foods, Inc., PO Box 712 , Buhl, Idaho 83316, USA
}

\begin{abstract}
An anti-infectious hematopoietic necrosis virus (IHNV) nucleoprotein monoclonal antibody, 1NDW14D $\left(\mathrm{IgG}_{1}\right)$, labeled with a streptavidin gold marker was utilized to monitor infection of juvenile rainbow trout and coho salmon with IHNV at the ultrastructural level. Juvenile fish were challenged with a virulent isolate of IHNV or mock-challenged with phosphate buffered saline. In both juvenile rainbow trout and coho salmon, the target area for infection by lHNV appeared to be the esophageal/cardiac stomach region (ECSR), particularly the mucus-secreting serous cardiac glands (MSSG). We previously found that, at the light microscopic and ultrastructural levels in rainbow trout, the MSSG form long continuous glands in association wath the esophageal mucosa located opposite the swimbladder pneumatic duct. In contrast, the coho salmon MSSG bud from the esophageal mucosa, forming dense bodies located posterior to the pneumatic duct. With the aid of a $20 \mathrm{~nm}$ immunogold marker labeling the nucleoproten of the virus, the progression of the infection was followed from the esophageal mucosa to the MSSG in both species. The immunogold marker was located in both the rainbow and coho salmon epithelial cells, which exhibited severe intercellular edema with separation of the mucosa at $24 \mathrm{~h}$ post challenge. The immunogold marker was also found in the MSSG of both species, with the rainbow trout exhibiting glandular cystic degeneration as early as $1 \mathrm{~h}$ post challenge, which further developed to a severe cystic degeneration by $24 \mathrm{~h}$. The coho salmon exhibited a similar but milder reaction to the virus. In both species, the $24 \mathrm{~h}$ post mock-challenged MSSG exhibited no morphological changes. When the infection was monitored in the MSSG of both rainbow trout and coho salmon at 1 and $24 \mathrm{~h}$ post viral challenge, a statistically significant difference between the 2 time points was detected within each fish species, suggesting that replication occurred in the MSSG. In addition, a statistically significant difference was detected between fish species at both 1 and $24 \mathrm{~h}$, indicating quantitatively that the virus is replicated more efficiently in the MSSG of rainbow trout than in the MSSG of coho salmon.
\end{abstract}

KEY WORDS: Rhabdovirus - Portal of entry - Mucus-secreting cardiac glands (MSSG) - Rainbow trout . Coho Salmon

\section{INTRODUCTION}

Infectious hematopoietic necrosis virus (IHNV) is an economically important rhabdovirus of cultured salmonid fish; however, it does not appear to possess the same virulence in all salmonid species. IHNV has

\footnotetext{
·Addressee for correspondence. E-mail: ristow@wsu.edu
}

been detected in a number of salmonids such as rainbow trout Oncorhynchus mykiss, sockeye salmon $O$. nerka, chinook salmon $O$. tschawytcha and chum salmon $O$. keta. Coho salmon $O$. kisutch and triploid hybrids (rainbow trout $\times$ coho salmon) (Parsons et al. 1986) appeared resistant to infections of IHNV until LaPatra et al. (1989) demonstrated the presence of virus in tissue extracts from naturally infected asymptomatic coho salmon. 
Even though the route of virus entry is not certain, studies have demonstrated virus budding from gill epithelial cells of adult rainbow trout at $9 \mathrm{~d}$ post infection (Yamamoto \& Clermont 1990), and viral titers were detected in adult sockeye salmon gills $14 \mathrm{~d}$ post IHNV exposure (Mulcahy et al. 1983). Recently, IHNV has been detected in gill lamellae of steelhead trout fry at 2 d post challenge (Drolet et al. 1994). Chilmonczyk \& Monge (1980) demonstrated that pillar (pilaster) cells of adult rainbow trout gills expressed viral hemorrhagic septicemia virus (VHSV), another rhabdovirus of salmonids, $24 \mathrm{~h}$ after intracardiac injections and $3 \mathrm{~d}$ after waterbath challenge. Yasutake \& Wales (1983) demonstrated the involvement of eosinophilic granule cells located in the esophagus/cardiac stomach region of naturally infected adult rainbow trout. C. E. Smith (cited in Smail \& Munro 1989) reported generalized necrosis of the small intestine eosinophilic granular cells in IHNV-infected adult rainbow trout; however, these eosinophilic granule cells are absent in rainbow trout alevin and small fry (Bolton 1933, Kumura \& Kudo 1975).

Our laboratory has produced a library of monoclonal antibodies to the nucleoprotein (N) and glycoprotein (G) of IHNV which have proved useful for detecting IHNV, mapping epitopes and epizootiological studies (Ristow \& Arnzen 1989, Ristow \& Arnzen de Avila 1991, Xu et al. 1991). Two monoclonal antibocties, 1NDW14D $\left(\operatorname{lgG}_{1}\right)$ and 3GH135L $\left(\operatorname{IgG}_{1}\right)$, universally recognize $N$ and $G$, respectively, of North American isolates of IHNV by fluorescence (Ristow \& Arnzen 1989. Arnzen et al. 199.1, Danton et al. 1994).

In the present study, the anti- $N$ monoclonal antibody 1NDW14D, labeled with a streptavidin gold marker, was used to quantitatively monitor (Kehle \& Herzog 1987, Enestrom 1993) the in vivo infection of IHNVchallenged and mock-challenged juvenile rainbow trout and coho salmon at the ultrastructural level.

\section{MATERIALS AND METHODS}

Virus and fish viral challenges. The 1990 isolate of infectious hematopoietic necrosis virus (IHNV), 220-90, was isolated from commercially-reared rainbow trout at Clear Springs Foods, Inc. (Buhl, ID, USA) (LaPatra et al. 1991). Eight groups of 5 juvenile stock rainbow trout Oncorhynchus mykiss each $(0.32 \mathrm{~g}$ mean weight) were obtained from Clear Springs Foods Domsea stock coho salmon $O$. kisutch 10.5 g mean weight) were obtained from AquaSeed (Rochester, WA, USA) Fish were held in a separate 221 aquaria receiving ultraviolet-disinfected, single-pass springwater at a constant water temperature $\left(15^{\circ} \mathrm{C}\right)$ prior, during and post challenge. All fish were fasted $3 \mathrm{~d}$ prior to being challenged with $10^{5}$ plaque-forming units (pfu) $\mathrm{ml}^{-1}$ of IHNV isolate 220-90 or mock-challenged with phosphate buffer saline (PBS) ( $\mathrm{pH} 7.0$ ). In vivo challenges of randomly selected fish were conducted in a closed system by immersing fish in virus or PBS for $1 \mathrm{~h}$. Following challenge, fish were removed at 1 and $24 \mathrm{~h}$, euthanized and placed in $6 \%$ paraformaldehyde containing $0.5 \%$ glutaraldehyde in $0.1 \mathrm{MPBS}$ ( $\mathrm{pH} 7.4$ ) fixative for $15 \mathrm{~min}$, then rinsed 2 times in PBS ( $\mathrm{pH}$ 7.4). Their abdomens were opened along the midventral line, and the fish were placed in fresh fixative and stored at $4^{\circ} \mathrm{C}$. Selected tissues were then processed for transmission electron microscopy (TEM).

Processing for standard TEM. Four juvenile rainbow trout and 4 juvenile coho salmon were randomly selected at time points 1 and $24 \mathrm{~h}$ post IHNV challenge and processed for TEM. Four randomly selected 24 h mock challenge fish from each species were also processed in the same manner. Fish were dissected after fixation, and samples of gill, esophagus/cardiac stomach region, pyloric caeca and small intestine were rinsed in $0.1 \mathrm{M}$ PBS overnight at $4^{\circ} \mathrm{C}$. Tissues were processed for transmission electron microscopy through an ethanol dehydration series $(40,50,70,80$, 95 and $100 \%, 10$ min each), followed by a $1: 1$ mixture of $100 \%$ ethanol to $100 \%$ propylene oxide for infiltration for $15 \mathrm{~min}$. Samples were then exposed to $100 \%$ propylene oxide for $15 \mathrm{~min}$. Finally, samples were exposed to 1:1 mixture of propylene oxide to Medcast medium grade epoxy (Ted Pella, Redding, CA, USA) for infiltration by rotating the tissue samples overnight at room temperature. (Note: to preserve antigenicity, the tissue was not exposed to osmium tetroxide preembedding stain.) The samples were then embedded in Medcast medium grade epoxy and cured for $24 \mathrm{~h}$ at $50^{\circ} \mathrm{C}$. Parallel thick sections (1 to $2 \mu \mathrm{m}$ ) were cut with an LKB (model 8800 Ultrotome III) ultramicrotome, using a glass knife to obtain parallel sections of $24 \mathrm{~h}$ post mock and 1 and $24 \mathrm{~h}$ post IHNV-challenged rainbow trout and coho salmon tissue. Thin sections (100 to $200 \mathrm{~nm}$ ) were then cut, using a Dupont diamond knife, and mounted on noncoated 300 mesh nickel grids.

Immunogold labeling. Before incubation with primary antibody, tissue sections were rehydrated with distilled water and washed 3 times with $0.1 \mathrm{M}$ trisbuffered saline (TBS) ( $\mathrm{pH}$ 7.2). To prevent non-specific binding, tissue sections were blocked twice for 5 min each with $5 \%$ bovine serum albumin (BSA) in 0.1 M TBS ( $\mathrm{pH} 7.2)$ containing $0.1 \%$ Triton $\mathrm{X}-100$ and $100 \mathrm{mM}$ glycine to remove excess glutaraldehyde. Grids were transferred to a second blocker of $1 \%$ gelatin in 0.1 M TBS ( $\mathrm{pH} 7.2$ ) plus $0.1 \%$ Triton X-100 for $10 \mathrm{~min}$ to prevent non-specific binding. Excess fluid was removed, and grids were incubated in anti- 
$\mathrm{N}$ monoclonal antibody (1NDW14D) at a 1:50 dilution in $1 \%$ BSA $-0.1 \mathrm{M}$ TBS plus $0.1 \%$ Triton $\mathrm{X}-100$ $\left(\mathrm{pH} \mathrm{7.2)}\right.$ for $20 \mathrm{~h}$ at $4^{\circ} \mathrm{C}$. Mock-infected grids were treated the same as the IHNV-infected grids, except that one set was not exposed to the primary antibody, anti-N, but was labeled with the biotinylated secondary antibody and the streptavidin $20 \mathrm{~nm}$ gold marker to check for non-specific binding. After primary antibody incubation, grids were washed 10 times for 5 min each with 0.1 M TBS-0.1\% Triton X100 (pH 8.6) (washing buffer) to prevent non-specific binding. A biotinylated secondary antibody (goat antimouse IgG:Hyclone EA-1063-U, Logan UT) diluted $1: 200$ in $1 \%$ BSA-0.1 M TBS plus $0.1 \%$ Triton X-100 was applied, and grids were incubated for $1 \mathrm{~h}$ at room temperature. After washing grids 10 times for 5 min each with washing buffer, streptavidin gold (20 nm) (Ted Pella no. 15843, Redding, CA) diluted 1: 200 in $1 \%$ BSA-TBS plus $0.1 \%$ Triton $\mathrm{X}-100$ was applied and grids were incubated for $1 \mathrm{~h}$ at room temperature. Grids were then rinsed with $0.1 \mathrm{M}$ TBS$0.1 \%$ Triton $\mathrm{X}-100(\mathrm{pH} 8.6)$, rinsed with distilled water and post-fixed in $1.5 \%$ glutaraldehyde in $0.1 \mathrm{M}$ sodium cacodylate buffer for $10 \mathrm{~min}$. Grids were washed in distilled water and post-stained with uranyl acetate for $8 \mathrm{~min}$, rinsed with distilled water air dried and examined, using a Zeiss EM 10A or a Hitachi 600 transmission electron microscope (Beesley 1989, Bartholomew et al. 1990).

Quantitative and statistical analysis of IHNV binding. Density of the immunogold labeling over the tissue sections from mucus-secreting serous glands (MSSG) of the rainbow trout and coho salmon esophagus/cardiac stomach region was evaluated to quantitatively determine IHNV antigen binding. A total of 8 representative MSSG micrographs for each species from the 3 treatments (4 rainbow trout and coho salmon at $24 \mathrm{~h}$ post mock challenge, 4 rainbow trout and coho salmon at $1 \mathrm{~h}$ post IHNV challenge, and 4 rainbow trout and coho salmon at $24 \mathrm{~h}$ post IHNV challenge) were evaluated for immunogold labeling. Since only the antigenic sites on the surface of the tissue section interact with the anti- $\mathrm{N}$ monoclonal antibody, the density of the immunogold label was determined for the area occupied by the MSSG on the thin sections. The surface area $\left(S_{\mathrm{a}}\right.$ in $\left.\mu \mathrm{m}^{2}\right)$ of each MSSG was measured from TEM negatives. The MSSG images were captured with an image analyzer computer program (Image NIH $1 / 52$ freeware program on a Quan 950 computer), projected onto a computer screen, the perimeter of each MSSG measured and the surface area calculated. The number of gold particles $\left(N_{\mathrm{i}}\right)$ present over each MSSG were counted, and the density $\left(N_{s}\right)$ of the gold label calculated according to the formula $N_{\mathrm{s}}=N_{\mathrm{i}} / S_{\mathrm{a}}$ (Weibel 1969). A completely randomized design with a 3-way treatment structure statistical analysis ANOVA was then conducted ( $\mathrm{Zar}$ 1974).

\section{RESULTS}

At the light microscopic level, the esophagus/cardiac stomach region differed between the 2 species, particularly the architecture of the mucosa and the structure of MSSG (Fig. 1). The MSSG in both species were formed from the esophageal mucosa. The rainbow trout MSSG formed a long continuous gland that is in association with the mucosa, possibly allowing a portal of entry into the developing MSSG (Fig. 1A, B). In contrast, the coho salmon MSSG budded from the mucosa, forming dense clusters in the submucosa (Fig. 1C, D).

At the ultrastructural level, marked differences were noted between MSSG of mock-challenged and IHNVchallenged rainbow trout and coho salmon (Fig. 2). The MSSG of the rainbow trout exhibited cystic degeneration as early as $1 \mathrm{~h}$ post IHNV challenge (Fig. 2B), progressing to a severe cystic degeneration (Fig. 2C) by $24 \mathrm{~h}$ post challenge. In contrast, the MSSG from IHNV-challenged coho salmon appeared unaffected by the virus at $1 \mathrm{~h}$ (Fig. 2E) and may have exhibited a similar but milder reaction, as seen in the rainbow trout at $24 \mathrm{~h}$ post challenge (Fig. 2F). No changes were observed in either the rainbow trout or coho salmon $24 \mathrm{~h}$ post mock challenge MSSG (Fig. 2A, D).

With the aid of the immunogold marker, internalization of IHNV antigen was demonstrated in the esophagus/cardiac stomach mucosal epithelium of both rainbow trout (Fig. 3A) and coho salmon (Fig. 3B) via coated pits. Immunogold marker was also located in both rainbow trout and coho salmon MSSG (Fig. 4A, $B)$. The density of gold label increased significantly in rainbow trout MSSG (Table 1) which exhibited severe cystic degeneration, thus confirming the presence of viral antigens and associated pathology at 1 and $24 \mathrm{~h}$ post challenge (Fig. 2B, C). The coho salmon MSSG also displayed an increase in the density of the gold label (Table 1), confirming the presence of viral antigens, with no associated pathology at $1 \mathrm{~h}$, and a mild cystic reaction forming at $24 \mathrm{~h}$ post IHNV challenge (Fig. 2E, F). Fig. 5A, B shows the gold label attached to the endoplasmic reticulum of the epithelial cells located in the esophagus/cardiac stomach region of both species, indicating possible viral replication.

The mean density of the immunogold label located in the MSSG of each species at $24 \mathrm{~h}$ post mock challenge, 1 and $24 \mathrm{~h}$ post IHNV challenge, is shown in Table 1 . At $1 \mathrm{~h}$ post IHNV challenge, rainbow trout 

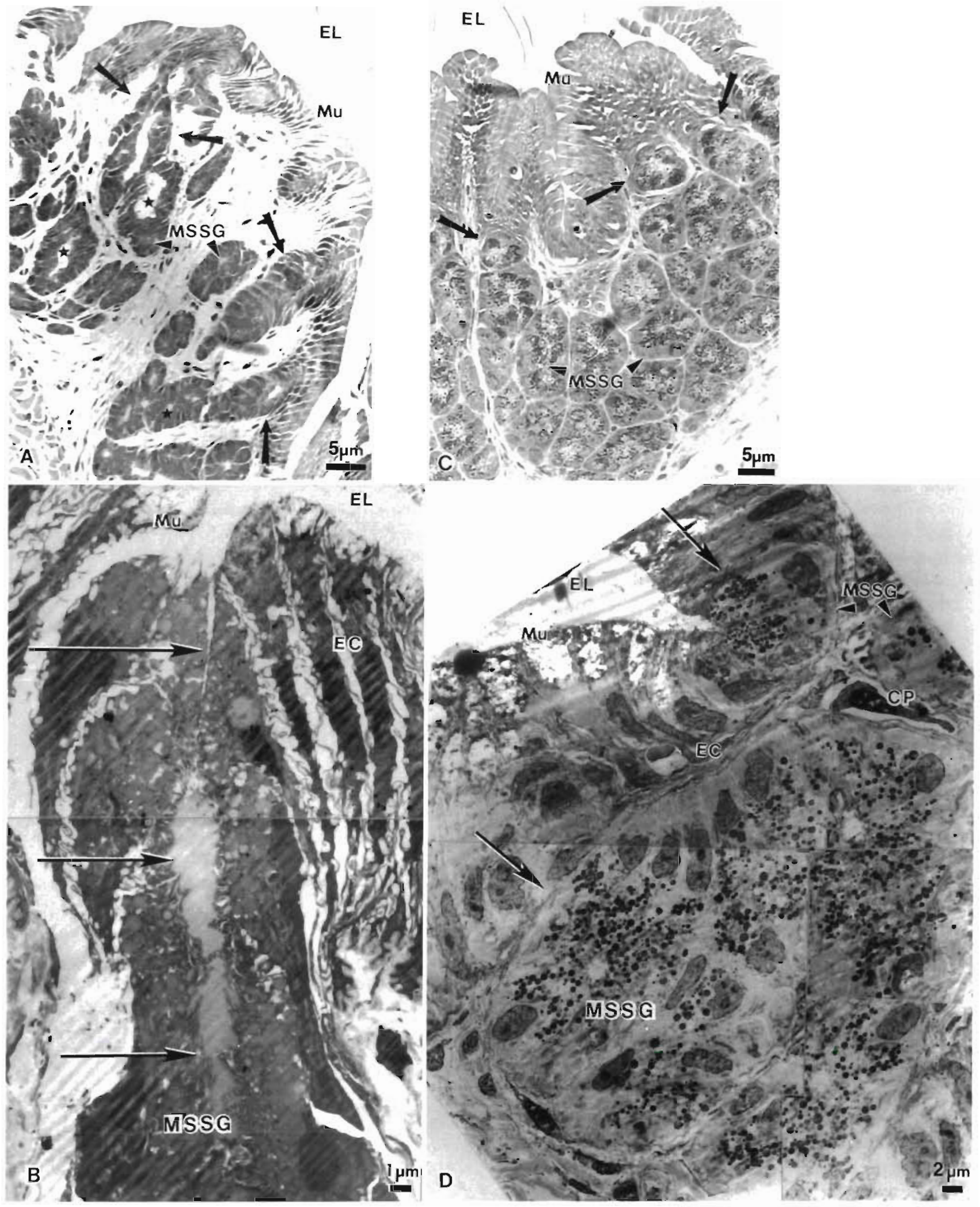

Fig. 1 Oncorhynchus mykiss and $O$. kisutch. Rainbow trout and coho salmon esophagus/cardiac stomach region at $24 \mathrm{~h}$ post IHNV challenge. (A) Representative light micrograph showing the long continuous forming MSSG (arrows) from the mucosa of rainbow trout and cystic degeneration of MSSG ( $\star$ ). (B) Representative transmission electron micrograph of the formation of rainbow trout MSSG $_{i}$ note the long continuous MSSG and the duct which is open to the ECSR lumen (arrows). (C) Representative light micrograph showing the budding of the MSSG (arrows) from the mucosa of coho salmon and cystic degeneration ( $\star$ ). (D) Representative transmission electron micrograph of the formation of coho salmon MSSG; note the budding of the MSSG (arrows). EL: esophagus lumen; Mu: mucosa; EC: epithelial cells; Cp: capillary; MSSG: mucus-secreting serous gland 

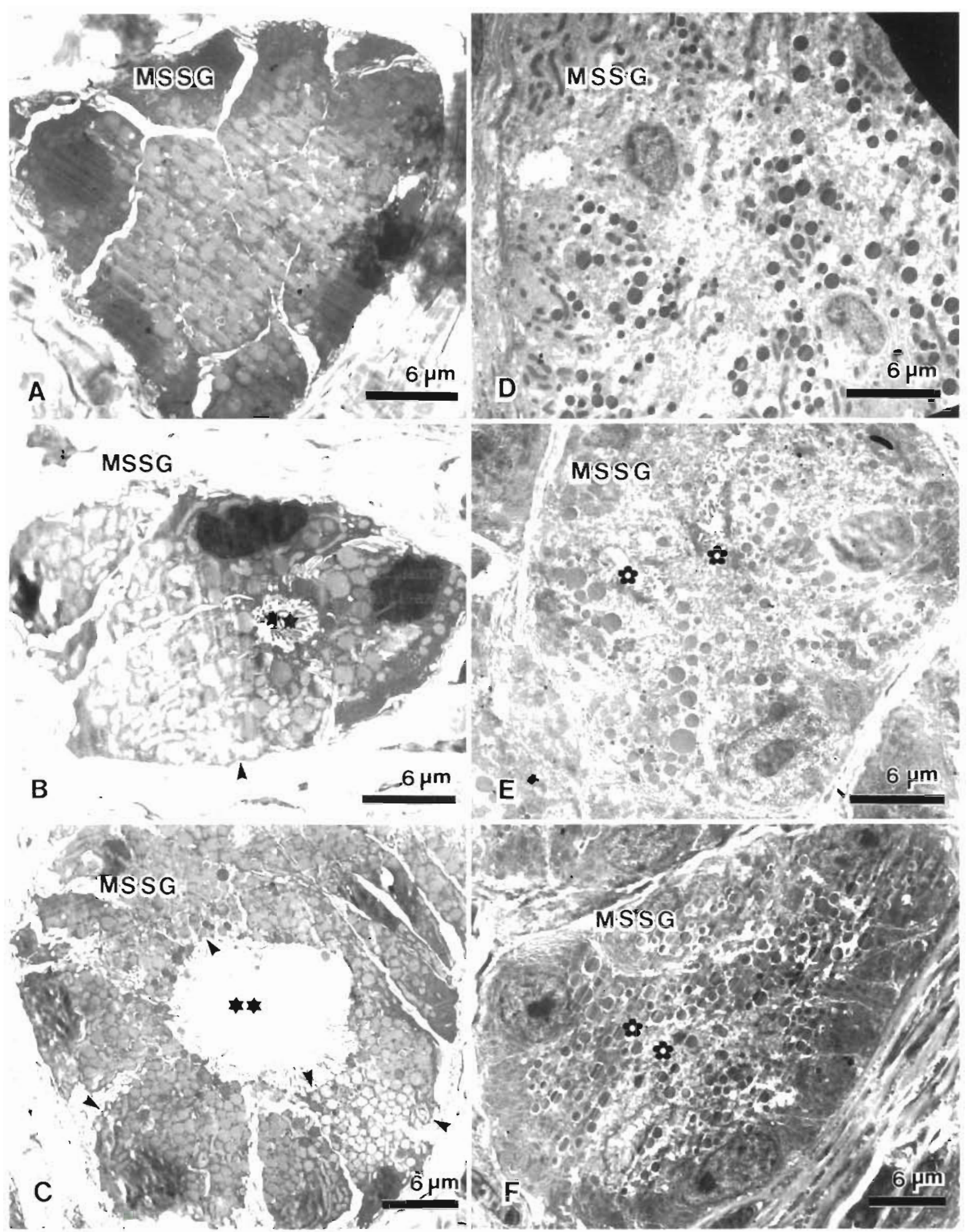

Fig. 2. Oncorhynchus mykiss and $O$. kisutch Representative transmission micrographs of (A-C) rainbow trout and (D-F) coho salmon MSSG at $24 \mathrm{~h}$ post mock challenge and 1 and $24 \mathrm{~h}$ post IHNV challenge. Note (A) and (D) $24 \mathrm{~h}$ post mock challenge tissues show no morphological changes, (B) and (E) 1 h post IHNV challenge, beginning of cystic degeneration ( $\$$, (F) 24 h post IHNV challenge, severe cystic degeneration in rainbow trout MSSG (C. and beginning of cystic degeneration in coho salmon MSSG (F * 


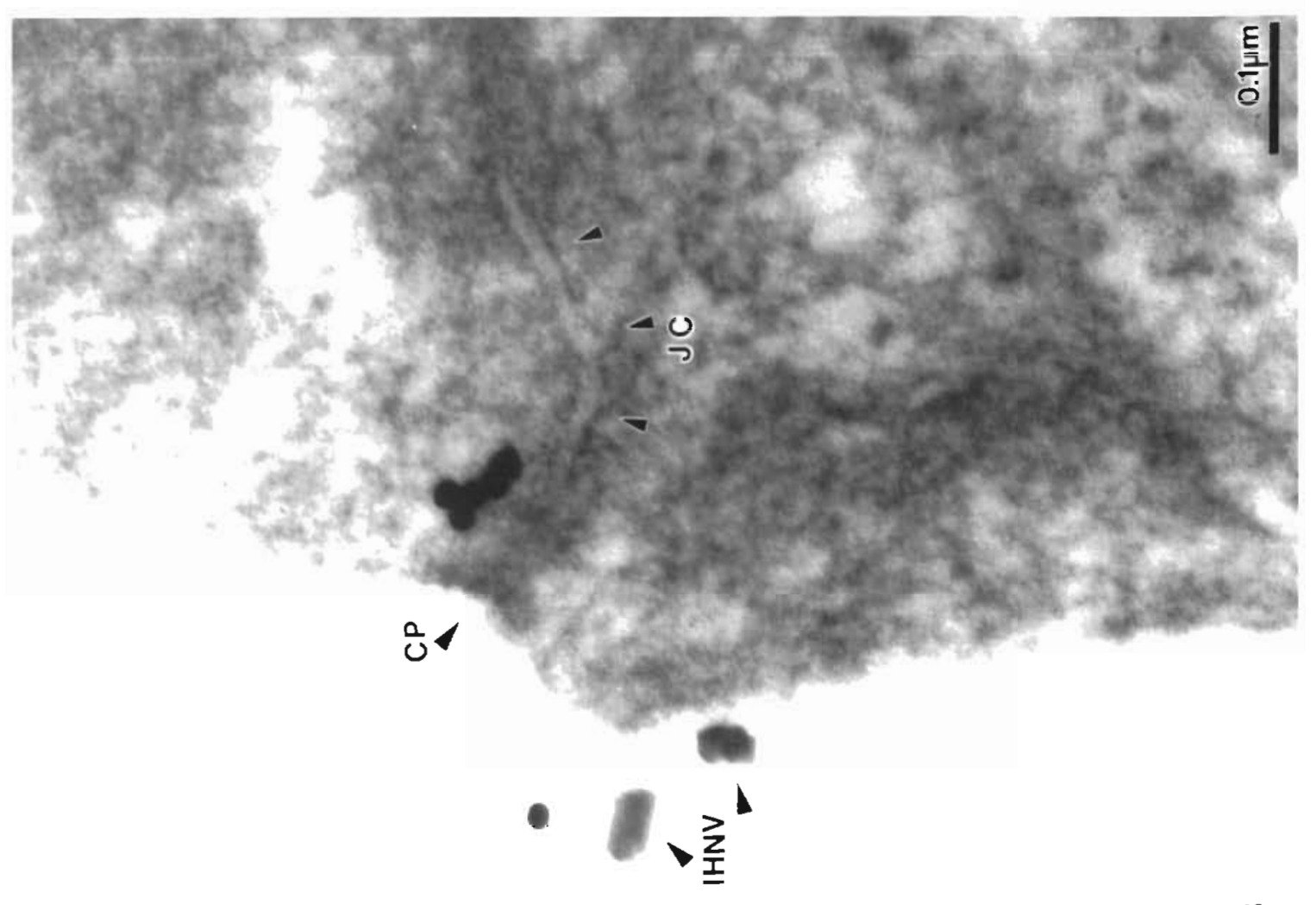

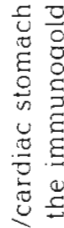

劣 $\frac{\pi}{3}$

응

号

뭄

䆚 $\frac{0}{\pi}$

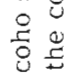

$\Phi$.

듬

공

3

3

를

这豆

5

듬

可

$\infty$

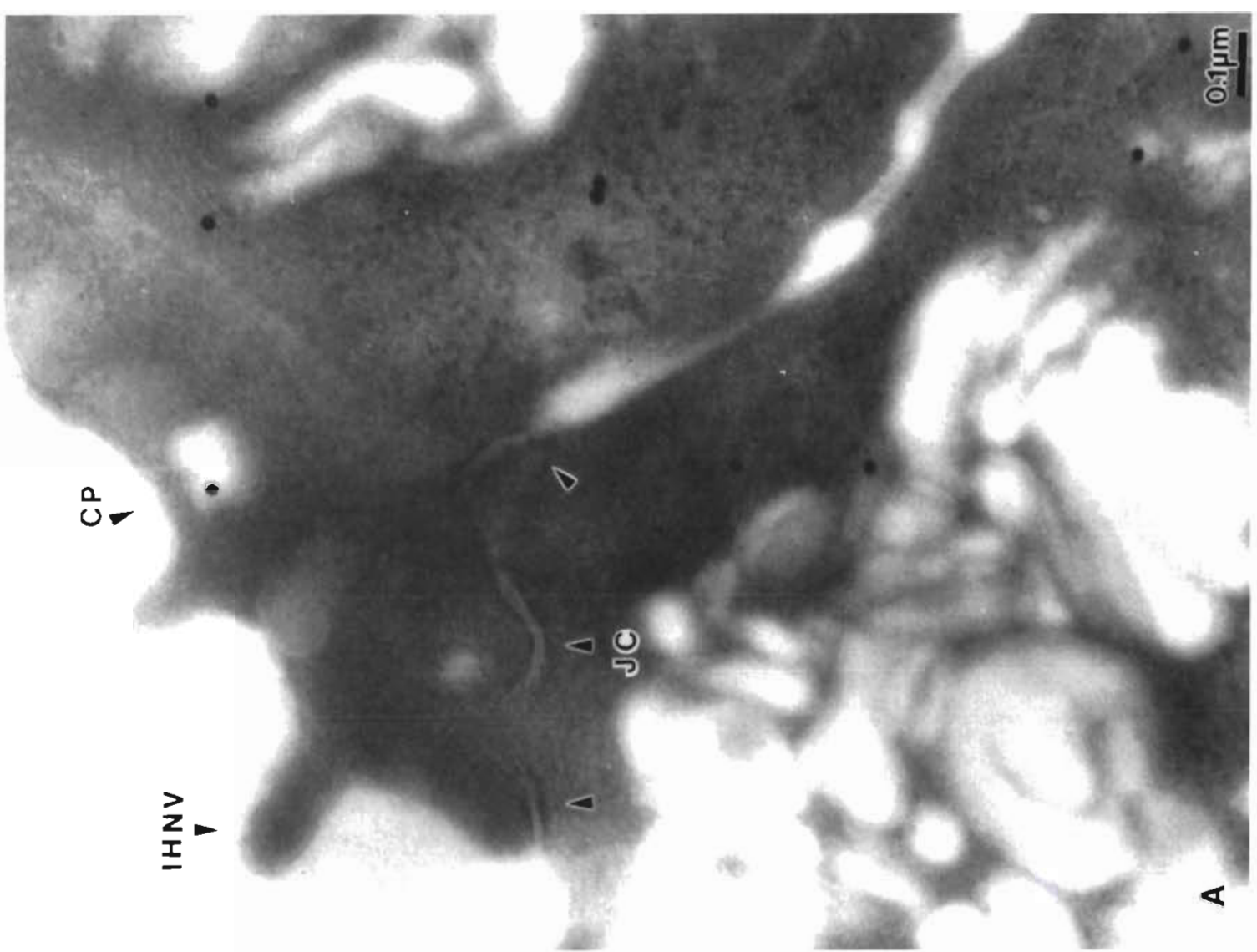

हैं

돌.

U⿺辶寸

E

员范

in

可

0

3

要

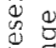

Q

$\varangle \frac{5}{4}$

就

$\pm$

ฮี

$\frac{\pi}{\pi}$

훙

芩

홍

:

ธี

क्ष 


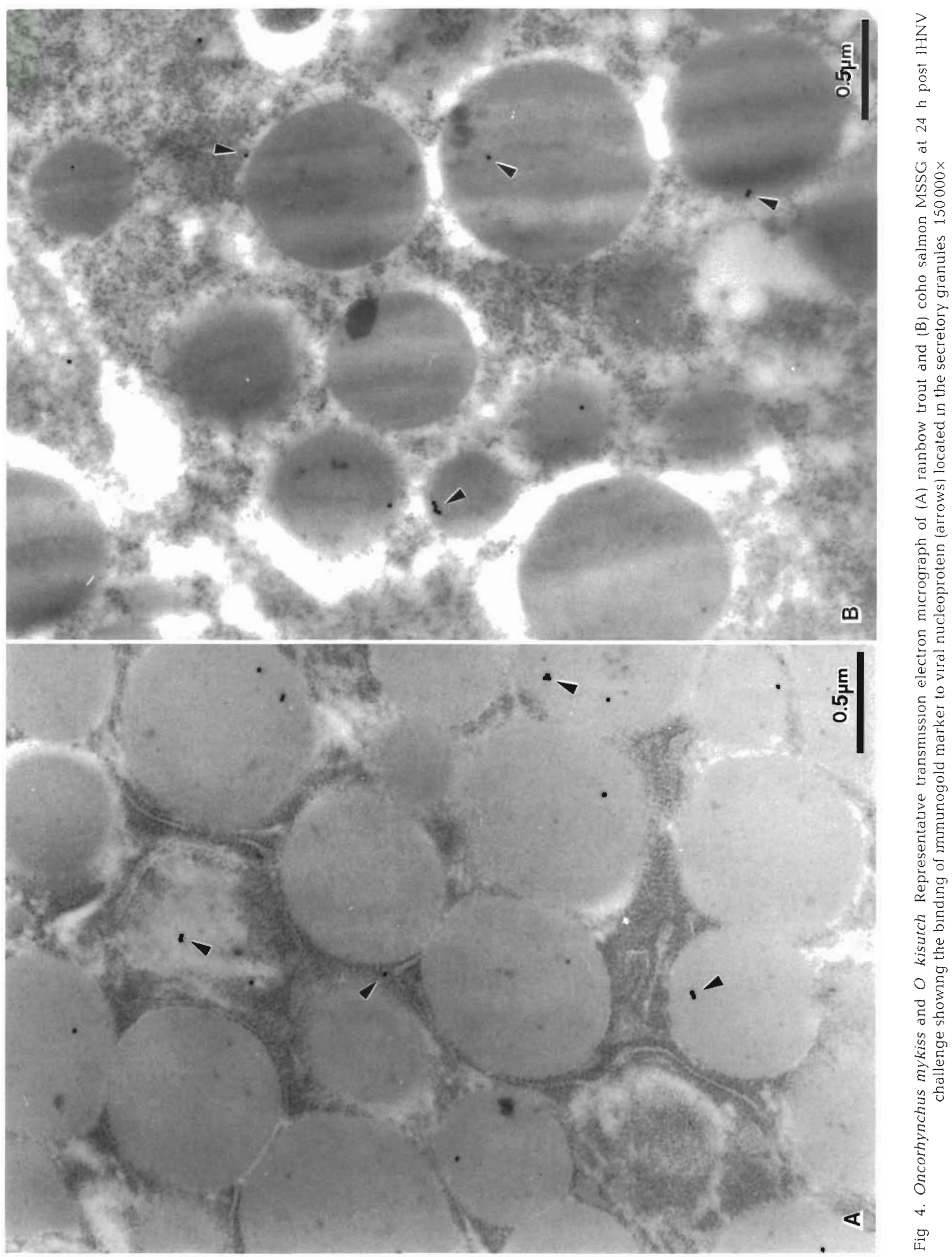




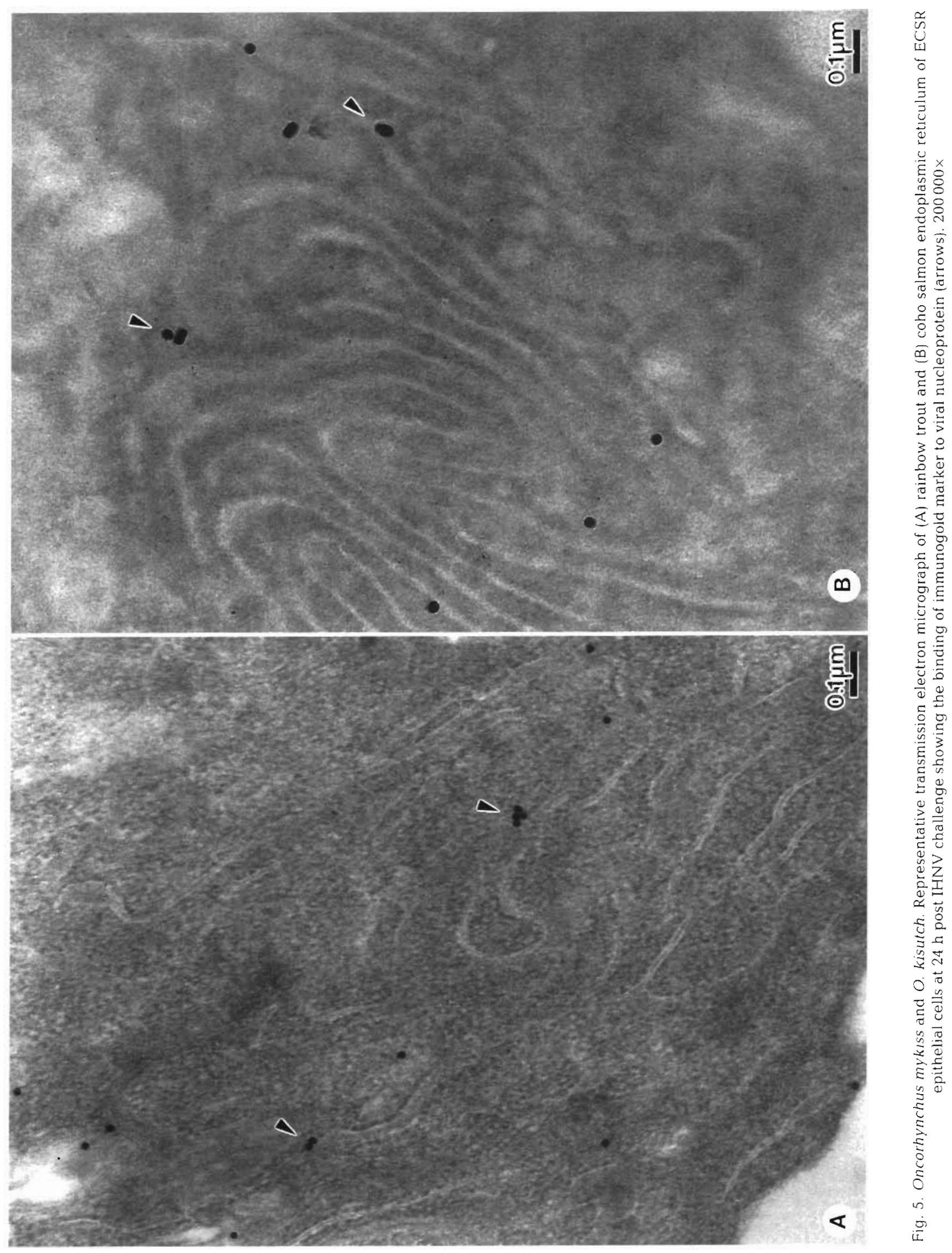


Table 1 Oncorhynchus mykiss and $O$. kisutch. Mean density of gold particles per $\mu \mathrm{m}^{2} \pm \mathrm{SD}$ of rainbow trout and coho salmon MSSG. $\mathrm{n}=4$ fish of each species for each treatment group, and 8 micrograph fields were counted per fish. All means are significantly different $(\mathrm{p}<0.05)$

\begin{tabular}{|lcc|}
\hline & Rainbow trout & Coho salmon \\
\hline Mock challenged 24 h & $0.3310 \times 10^{-3} \pm 0.0926$ & $0.2368 \times 10^{-3} \pm 0.0721$ \\
IHNV challenged 1 h & $1.5060 \times 10^{-3} \pm 0.6851$. & $0.7997 \times 10^{-3} \pm 0.1481$ \\
IHNV challenged 24h & $2.8775 \times 10^{-3} \pm 1.3552$ & $1.3225 \times 10^{-3} \pm 0.2562$ \\
\hline
\end{tabular}

mucus-secreting serous glands which are unique to particular fish families, such as Centrarchidae (bass, crappie and bluegill), Cyprinidae (shiners and minnows), Esocidae (pickerel and pike), Ictaluridae (catfish) and Percidae (perch). These MSSG produce 3 types of epithelial mucosubstance secretions which have been identified as: sulfomucins, sialomucins (sialic acids) and neutral mucosubstances (Reifel \& Travill 1977). Although comparisons are

had a greater mean density of gold particles per $\mu \mathrm{m}^{2}$ than coho salmon. At $24 \mathrm{~h}$ post IHNV challenge, the mean density of gold particles doubled in both species, suggesting viral replication. Low numbers of nonspecifically bound gold particles were detected in both species in the $24 \mathrm{~h}$ post mock challenge samples (Table 1). A statistically significant difference between 1 and $24 \mathrm{~h}$ was detected within both species, with rainbow trout tissue demonstrating a greater affinity for the immunogold label than coho salmon after viral exposure.

\section{DISCUSSION}

In juvenile rainbow trout and coho salmon, an early target area for IHNV is the esophagus/cardiac stomach region (ECSR), particularly the cardiac MSSG. Even though the susceptibility of rainbow trout to the virus has long been known, the route of entry is still under investigation. Coho salmon have traditionally been considered resistant to IHNV infection until LaPatra et al. (1989) demonstrated the presence of virus from tissue extracts of naturally infected asymptomatic fish. This study provides evidence of attachment and internalization of IHNV via coated pits in the ECSR mucosal epithelial cells and a potential viral replication site of IHNV in both species, as well as the involvement of the MSSG in viral antigen presentation, associated pathology and possible portal of entry.

In this study, the location and morphology of the MSSG differed between species, with the appearance of the MSSG occurring opposite the swimbladder pneumatic duct in juvenile rainbow trout and posterior to the pneumatic duct in juvenile coho salmon (Helmick et al. 1995; this issue). In addition, the swimbladder is adjacent to the anterior kidney, the primary target organ of IHNV (Wolf 1988). Since we detected morphological changes and immunogold label in rainbow trout MSSG (post viral exposure) which are located opposite the swimbladder duct, this area could be considered a portal of entry for viral infection.

Even though the role of the MSSG is not known in fish, Reifel \& Travill (1977) have identified 6 different types of limited, the submandibular salivary glands, nasal mucosal glands, parotid acinar glands and bronchial acinar glands of mammals, such as miniature pig, tree shrew, vampire bat, cat, rabbit, rat and opossum (Pinkstaff 1993, Tandler 1993), appear similar to fish MSSG. Mammalian mucus-secreting glands/serous cells are referred to as seromucous cells, which also secrete a sialic acid (sialomucin) and acidic sulfated (sulfomucin) glycoconjugate (Reifel \& Travill 1972) similar to fish mucin products. In human airways, the seromucous glands appear to be the primary defensive cell of the mucosa used to combat bacterial pathogens (Basbaum et al. 1990). It has been shown that Sendai viruses, a paramyxovirus (Markwell et al. 1984, Gershoni et al. 1986), and influenza A, B and C viruses, orthomyxoviruses (Herrler et al. 1985, Suzuki et al. 1985) bind to cell membrane components containing sialic acid, such as sialoglycoproteins and sialoglycolipids.

During the past 20 years, immunogold labeling techniques have become an invaluable aid in examining tissue by electron microscopy. Initially, direct immunogold labeling was utilized in identification and immunohistochemical localization of Salmonella antigens (Faulk \& Taylor 1971). Later, indirect labeling with gold markers was employed on thin sections for TEM (Romano et al. 1974, Roth et al. 1980). Quantitative ultrastructural immunocytochemical analyses is a relatively new area, giving quantitative measurements based on the density (number of gold particles) of immunogold label of particular size expressed as the number of gold particles per $\mu^{2}$ (Kehle \& Herzog 1987, Enestrom 1993). Since immunogold labeling is such a sensitive technique at the ultrastructural level, non-specific binding is more detectable than at the light microscopic level. At the ultrastructural level, the $20 \mathrm{~nm}$ immunogold particle gave optimum results.

Our results with immunogold labeling suggest that the MSSG of rainbow trout and coho salmon esophagus/cardiac stomach regions are one primary site of early IHNV attachment and are viral replication sites. The attachment of virus in both species was demonstrated, even though the coho salmon and coho salmon cell lines were originally thought to be virus resistant (Chen 1984, Lannan et al. 1984). The 24 h post 
mock challenge tissue samples also exhibited a low degree of immumogold binding because non-specific binding cannot be completely eliminated (Livesy et al. 1989). Statistical analyses of the distribution of the gold marker showed significant differences between species and within species, suggesting that viral replication occurred in MSSG of both species. In addition, a significant statistical difference was detected between fish species at both 1 and $24 \mathrm{~h}$, indicating that the viral protein is replicated more efficiently in the rainbow trout MSSG.

In summary, this study has shown that the ECSR mucosal epithelium is a site of viral attachment and internalization, and is a potential site for IHNV replication. Additionally, the ECSR, specifically the MSSG, plays a significant role in viral antigen replication and pathology.

Acknowledgements. The authors thank Dr Charles Meshul from the Veterans Hospital in Portland, Oregon, for technical advice on immunogold labeling; Dr Marc Evans from the Washington State Program in Statistics for statistical analyses of the data; Jerry Jones from Clear Springs Foods, Inc.; and Dr Tom Baldwin from the Washington Animal Disease Diagnostic Laboratory for their technical assistance. This is scientific paper 8099 from the College of Agriculture and Home Economics Research Center of Washington State University. This material is based upon work supported by the Cooperative State Research Service, United States Department of Agriculture through the Western Regional Aquaculture Center under agreement nos. 93-38500-8588 and 94-3800-0049. This work was also supported in part by USDA Special Aquaculture Grant no. 90-34123-5138.

\section{LITERATURE CITED}

Arnzen JM, Ristow SS, Hesson CP, Lientz J (1991) Rapid fluorescent antibody tests for infectious hematopoietic necrosis virus (IHNV) utilizing monoclonal antibodies to the nucleoprotein and glycoprotein. J aquat Anim Health 3:109-113

Bartholomew JL, Yamamoto T, Rohovec JS, Fryer JL (1990) Immunohisto-chemical characterization of a monoclonal antibody against Ceratomyxa shasta. J aquat Anim Health $2: 68-71$

Basbaum CB, Jany B, Finkbeiner WE (1990) The serous cell. A Rev Physiol 52:97-113

Beesley JE (1989) Colloidal gold: a new perspective for cytochemical marking. Oxford University Press, p 22

Bolton LL (1933) Basophile (mast) cells in the alimentary canal of Salmonid fishes. J Morph 54:549-582

Chen MF (1984) Comparative susceptibility of salmonid fish lines to five isolates of infectious hematopoietic necrosis virus, and biological properties of two plaque variants. $\mathrm{PhD}$ dissertation, Oregon State University, Corvallis

Chilmonczyk S, Monge D (1980) Rainbow trout gill pillar cells: demonstration of inert particles, phagocytosis and involvement in viral infection. J Reticuloendo Soc 28:327-333

Danton M, Ristow SS, Hattenberger-Baudouy AM, de Kinkelin P (1994) Typing of French isolates of infectious hematopoietic necrosis virus (IHNV) with monoclonal antibodies using indirect immunofluorescence. Dis aquat Org 18:223-226

Drolet BS, Rohovec JS, Leong JC (1994) The route of entry and progression of infectious hematopoietic necrosis virus in Oncorchynchus mykiss: a sequential immunohistochemical study. J Fish Dis 17:337-348

Enestrom S (1993) Quantitative ultrastructural immunocytochemistry. USA Micro Anal July:27-29

Faulk W. Taylor G (1971) An immunocolloid method for electron microscopy. Immunocytochem 8:1081-1083

Gershoni JM, Loapidot M, Zakai N, Loyter A (1986) Protein blot analysis of receptors: identification and characterization of the Sendai virus receptor. Biochim Biophys Acta 777:19-26

Helmick CM, Bailey JF, LaPatra S, Ristow S (1995) Histological comparison of infectious hematopoietic necrosis virus challenged juvenile rainbow trout Oncorhynchus mykiss and coho salmon $O$. kisutch gill, esophagus/cardiac stomach region, small intestine and pyloric caeca. Dis aquat Org 23:175-187

Herrler G, Rott R, Klenk HD (1985) Neuraminıc acıd is involved in the binding of influenza $\mathrm{C}$ virus to erythrocytes. Virology 141:144-147

Kehle T, Herzog $V$ (1987) Interactions between protein-gold complexes and cell surfaces: a method for precise quantitation. Eur J Cell Biol 45:80-87

Kumura N, Kudo S (1975) Fine structure of the stratum granulosum of the pyloric caeca of the rainbow trout. Jap J Ichthyol 22:16-22

Lannan CN, Winton JR, Fryer JL (1984) Fish cell lines: establishment and characterization of nine cell lines from salmonids. In Vitro 20:671-676

LaPatra SE, Fryer JL, Wingfield WH, Hedrick RP (1989) Infectious hematopoietic necrosis virus in coho salmon Oncorhynchus kisutch. J aquat Anim Health 1:277-280

LaPatra SE, Lauda KA, Morton AW (1991) Antigenic and virulence comparison of isolates of infectious hematopoietic necrosis virus from the Hagerman Valley, Idaho, USA. In: Proceedings of the second international symposium on viruses of lower vertebrates. Oregon State University Press, Corvallis, p 125-129

Livesy SA, Buescher ES, Krannig GL, Harrison DS, Linner JG, Chiovetti R (1989) Human neutrophil granules heterogeneity: immunolocalization studies using cryofixed, dried and embedded specimens. Scan Elect Micro 3:231-240

Markwell MAK, Fredman P, Svennerholm L (1984) Receptor ganglioside content of three hosts for Sendai virus. Biochim Biophys Acta 775:7-16

Mulcahy DM, Pascho RJ, Jenes CK (1983) Detection of infectious haematopoietic necrosis virus in river water and demonstration of waterborne transmission. J Fish Dis 6: $321-330$

Parsons JE, Busch RA, Thorgaard GH, Scheerer PD (1986) Increased resistance of triploid rainbow trout $x$ coho salmon hybrids to infectious hematopoietic necrosis virus. Aquaculture 57:337-343

Pinkstaff CA (1993) Serous, seromucous and special serous cells in salivary glands. Microsc Res Tech 26:21-31

Reifel CW, Travill AA (1972) Structure and carbohydrate histochemistry of postnatal canine salivary glands. Am J Anat 134:377-393

Reifel CW, Travill AA (1977) Structure and carbohydrate histochemistry of the esophagus in ten teleostean species. J Morph 152:303-314

Ristow SS, Arnzen JM (1989) Development of monoclonal antibodies that recognize a Type-2 specific and common epitope on the nucleoprotein of infectious hematopoietic necrosis virus. J aquat Anim Health 1:119-125 
Ristow SS, Arnzen de Avila JM (1991) Monoclonal antibodies to the glycoprotein and nucleoprotein of infectious hematopoietic necrosis virus (IHNV) reveal differences among isolates of the virus by fluorescence, neutralization and electrophoresis. Dis aquat Org 11:105-115

Romano E, Stolinski C, Huges-Jones NC (1974) Ultrastructural localization of intracellular antigens by the use of Protein A-gold complex. Immunocytochem 11:521-522

Roth J, Bendayan M, Orci L. (1980) FITC-protein A-gold complex for light and electron microscopic immunocytochemistry. J Histochem Cytochem 28:55-57

Smail DM, Munro ALS (1989) The virology of teleosts. In: Roberts RJ (ed) Fish pathology. Bailliere Tindall, London, p 208-209

Suzuki Y, Matsunaga M, Matsumoto M (1985) Acetylneuraminyl-lactosylceramide, GM3-NeuAc, a new influenza A virus receptor which mediates the absorption-fusion process of viral infection. Binding specificity of influenza virus $\mathrm{A} / \mathrm{Aichi} / 2 / 68(\mathrm{H} 3 \mathrm{~N} 2)$ to membrane-associated GM3 with different molecular species of sialic acid. J Biol Chem 260:1362-1365

Responsible Subject Editor: F. M. Hetrick, College Park, Maryland, USA
Tandler B (1993) Introduction to mammalian salivary glands. Microsc Res Tech 26:1-4

Weibel ER (1969) Stereological principles for morphometry in electron microscopic cytology. Internat Rev Cytol 26: $235-302$

Wolf $\mathrm{K}$ (1988) Infectious hematopoietic necrosis. In: Wolf $\mathrm{K}$ (ed) Fish viruses and fish viral diseases. Cornell University Press, Ithaca, NY, p 83-114

Xu L, Mourich D, Ristow SS, Arnzen JM, Leong J (1991) Epitope mapping and characterization of the infectious hematopoietic necrosis virus glycoprotein with fusion proteins synthesized in Escherichia coli. J Virol 65:1611-1615

Yamamoto T, Clermont TJ (1990) Multiplication of infectious hematopoietic necrosis virus in rainbow trout following immersion infection: organ assay and electron microscopy. $J$ Aquat Anim Health 2:261-270

Yasutake WT, Wales JH (1983) Microscopic anatomy of salmonids: an atlas. US Dept of the Interior, Fish and Wildlife Service Publ 150, Washington, DC, p 25

Zar JH (1974) Biostatistical analysis. Prentice-Hall, Englewood Cliffs, NJ

Manuscript first received: February 1, 1995

Revised version accepted: April 14, 1995 